\title{
Assessment of the ozone sensitivity of 22 native plant species from Mediterranean annual pastures based on visible injury
}

\author{
V. Bermejo, B.S. Gimeno*, J. Sanz, D. de la Torre, J.M. Gil \\ Ecotoxicology of Air Pollution, CIEMAT (Ed. 70), Avda. Complutense 22, Madrid 28040, Spain
}

\begin{abstract}
Ozone $\left(\mathrm{O}_{3}\right)$ phytototoxicity has been reported on a wide range of plant species, inducing the appearance of specific foliar injury or increasing leaf senescence. No information regarding the sensitivity of plant species from dehesa Mediterranean grasslands has been provided in spite of their great biological diversity. A screening study was carried out in open-top chambers (OTCs) to assess the $\mathrm{O}_{3}$-sensitivity of 22 representative therophytes of these ecosystems based on the appearance and extent of foliar injury. A distinction was made between specific $\mathrm{O}_{3}$ injury and non-specific discolorations. Three $\mathrm{O}_{3}$ treatments (charcoal-filtered air, non-filtered air and non-filtered air supplemented with $40 \mathrm{nll}^{-1} \mathrm{O}_{3}$ during 5 days per week) and three OTCs per treatment were used. The Papilionaceae species were more sensitive to $\mathrm{O}_{3}$ than the Poaceae species involved in the experiment since ambient levels induced foliar symptoms in $67 \%$ and $27 \%$, respectively, of both plant families. $\mathrm{An}_{3}$-sensitivity ranking of the species involved in the assessment is provided, which could be useful for bioindication programmes in Mediterranean areas. The assessed Trifolium species were particularly sensitive since foliar symptoms were apparent in association with $\mathrm{O}_{3}$ accumulated exposures well below the current critical level for the prevention of this kind of effect. The exposure indices involving lower cut-off values (i.e. $30 \mathrm{nl}^{-1}$ ) were best related with the extent of $\mathrm{O}_{3}$-induced injury on these species.
\end{abstract}

Keywords: Grasslands; Dehesa; Clover; Critical levels; Foliar damage

\section{Introduction}

Tropospheric ozone $\left(\mathrm{O}_{3}\right)$ has been reported to reach phytotoxic levels in European rural areas (EMEP, 2002). There is concern about the harm this pollutant might pose to semi-natural grassland vegetation, since it is expected that the different $\mathrm{O}_{3}$ sensitivity of these plant species might induce changes in the floristic composition of plant communities (Fuhrer et al., 1994). Moreover, grassland ecosystems are particularly endangered by the interaction of other global-change components such as alterations in land-use, climate, nitrogen deposition, biotic exchange or atmospheric carbon dioxide (Sala et al., 2000). Therefore, $\mathrm{O}_{3}$ effects on these ecosystems should be assessed to effectively reduce anthropogenic impacts on them.

Early experiments concerning $\mathrm{O}_{3}$ effects on seminatural plant species were focused on the detection of foliar visible injury following their exposure to elevated $\mathrm{O}_{3}$ concentrations (Ashmore et al., 1987). Recent research has been carried out exposing herbaceous plants from different communities to realistic $\mathrm{O}_{3}$ levels. This is the case of the studies carried out by Ashmore et al. (1995), Pleijel and Danielsson (1997), Bergmann et al. (1999) and Franzaring et al. (2000) on the most common herbaceous taxa of northern and centralEuropean flora. However, no information exists on the $\mathrm{O}_{3}$ sensitivity of herbaceous species from Mediterranean grasslands. This is particularly distressing since plant 
diversity in some of these ecosystems, such as the dehesa-type grasslands, is quite remarkable (Pineda et al., 1981), and also because ambient $\mathrm{O}_{3}$ levels recorded in the Mediterranean region have been reported as phytotoxic (Fumagalli et al., 2001; Nali et al., 2002; Bermejo et al., 2002). Moreover, recent experimental work (Madkour and Laurence, 2002) has described the high sensitivity of a local Egyptian cultivar of Trifolium alexandrinum, driving attention to potential damage in the southern-Mediterranean area.

The dehesas represent an example of sustainable management of natural resources in the Iberian Peninsula, covering agricultural, timber and extensive livestock exploitation. The typical vegetation of dehesa ecosystems is composed of cleared oak woodlands with a grassland understorey. Annual species represents up to $71 \%$ of the herbaceous species from these ecosystems (Marañón, 1985). Large spatial and temporal fluctuations in floristic composition occur depending on tree coverage, slope-valley gradients, grazing pressure and meteorological conditions (Peco et al., 1998; San Miguel, 1994). As a result, plant species richness of these ecosystems is quite remarkable, 30 species per $400 \mathrm{~cm}^{2}$ (Pineda et al., 1981). The most characteristic species of these grasslands belong to the Papilionaceae and Poaceae families. Several studies have reported a great sensitivity to $\mathrm{O}_{3}$ of Papilionaceae plants in opposition to most of Poaceae species (see the review carried out by Davison and Barnes, 1998). Both taxa have different roles in the ecosystem, mainly in nitrogen cycling, and they also represent dissimilar nutritive sources for the livestock. Therefore, the assessment of the $\mathrm{O}_{3}$ sensitivity of the plants from these communities is quite appealing since this pollutant might have an impact on the structure, diversity, function and humanutility of these ecosystems belonging to the Mediterranean basin, an area that has been considered as an "hyper-hot" candidate for conservation support (Myers et al., 2000).

When plants are exposed to realistic concentrations, screening studies aiming to assess the sensitivity of a wide range of plants to air pollutants are suitable for the determination of thresholds of injury and may have implications in risk assessment or legislative initiatives. The United Nations Economic Commission for Europe (UN ECE) is leading one of the most comprehensive efforts to control transboundary air pollution through the assessment of the areas, where $\mathrm{O}_{3}$ levels exceed its phytotoxicity levels, also termed critical levels. Critical level has been defined as the pollutant concentration above which direct effects on receptors, such as plants, ecosystems or materials, may occur according to present knowledge (UN ECE, 1988). Ozone critical levels have been proposed for the protection of crops, semi-natural vegetation and forest-tree species (Fuhrer and Achermann, 1999).
The short-term $\mathrm{O}_{3}$ critical level for the prevention of foliar injury on herbaceous plants was derived from the results of a pan-European experiment carried out under the framework of the International Cooperative Programme (ICP) on the effects of air pollution on natural vegetation and crops (ICP vegetation). This experiment involved the ambient exposure of $T$. repens and $T$. subterraneum following a standardised protocol (Benton et al., 2000). Ozone-induced foliar injury was found to be related to the $\mathrm{O}_{3}$ exposure corresponding to the 5 days prior to the appearance of visible symptoms. Since air vapour pressure deficit (VPD) modulated $\mathrm{O}_{3}$ phytotoxicity, the short-term critical level was established at AOT40 (accumulated exposure over a threshold of $40 \mathrm{nl} \mathrm{l}^{-1}$ ) values of 200 and $500 \mathrm{nl} \mathrm{l}^{-1} \mathrm{~h}$ when mean VPD $(09: 30-16: 30)$ is below or above $1.5 \mathrm{kPa}$, respectively. Tonneijck and Van Dijk (2002) have reported injury on $T$. subterraneum with AOT40 values below $200 \mathrm{nl}^{-1} \mathrm{~h}$. Therefore, it appears that this critical level needs further revision.

This work presents the results of an experiment that was carried out with the following objectives: (1) to rank $\mathrm{O}_{3}$ sensitivity of therophytic plants from acidic dehesa pastures according to the appearance of foliar visible injury; (2) to assess whether differences in sensitivity could be attributed to certain plant genus or families, and (3) to evaluate the present short-term critical level for $\mathrm{O}_{3}$-injury development.

\section{Materials and methods}

\subsection{Experimental site}

The experiment was carried out at Sant Jaume d'Enveija, Spain $\left(40^{\circ} 41^{\prime} \mathrm{N}, 0^{\circ} 47^{\prime} \mathrm{E}\right)$. No major air pollutant sources that might have affected the results are located in the vicinity of the experimental site.

\subsection{Plant material}

All the species involved in this study are annual plants from dehesa acidic grasslands (Allué Andrade and Tella, 1986). Annual species are more predominant than perennials due to the extreme meteorological conditions occurring during summer and winter.

Most of the seeds were collected from a typical dehesa located North of Madrid (Dehesa de Moncalvillo, Guadalix de la Sierra, Madrid; $40^{\circ} 40^{\prime} \mathrm{N} 03^{\circ} 46^{\prime} \mathrm{W}$ ). The germoplasm bank of the Agriculture and Environment Council from the Extremadura Autonomous Community supplied the $T$. striatum, $T$. subterraneum, $T$. angustifolium and Ornithopus compressus seeds, collected at different sites from central-western areas of the Iberian peninsula. The Spanish $T$. subterraneum cv. Zujar was used in the experiments. 
All seeds of Papilionaceae species were immersed during $24 \mathrm{~h}$ in a Germinator ${ }^{\mathrm{C}}$ solution (Agro-Orgánicos Mediterráneos S.L., Granada, Spain) to ensure homogeneous germination. When seeds were swollen, they were sown in a $50 \%$ neutral peat and $50 \%$ vermiculite substrate. Poaceae seeds did not experience any pretreatment and they were sown in the same substrate as Papilionaceae seeds. Seedlings were transplanted to 2.51 pots with a $50 \%$ peat, $30 \%$ vermiculite and $20 \%$ perlite substrate and $2 \mathrm{~kg} \mathrm{~m}^{-3}$ of a slow-release fertiliser (NPK:15/8/11). Plants were irrigated with a droplet system to ensure adequate and homogeneous water availability to plant material.

\subsection{Ozone treatments}

The same day the plants were transplanted into pots they were introduced in slightly modified NCLAN-type open-top chambers (OTCs) (see Gimeno et al., 1999). Three $\mathrm{O}_{3}$ treatments were used: charcoal-filtered air (CFA) presenting subphytotoxic $\mathrm{O}_{3}$ levels, non-filtered air (NFA) with close to ambient $\mathrm{O}_{3}$ levels and nonfiltered air supplemented with $40 \mathrm{nl}^{-1} \mathrm{O}_{3}$ from 07:00 to 17:00 (GMT) 5 days week $^{-1}$ (NFA + ). Ozone concentrations in the NFA + treatment were in the range of those reported by Plaza et al. (1997) in the areas where these plant communities are present. Four to six plants of each species were introduced in each chamber and three OTC replicates were used for each $\mathrm{O}_{3}$ treatment. An automatic system provided a continuous monitoring of $\mathrm{O}_{3}$, sulphur dioxide and nitrogen oxides concentrations in the different treatments along with meteorological parameters such as wind speed and direction, air temperature and relative humidity, and photosynthetic active radiation (PAR). A complete description of the chambers and the operation of the system is provided in Pujadas et al. (1997) and Alonso et al. (2001). Details on the dates the plants were introduced in the chambers and the length of $\mathrm{O}_{3}$ exposure in the different treatments can be found in Tables 1 and 2 .

\subsection{Visible injury assessment}

Daily evaluations of $\mathrm{O}_{3}$-induced visible injury were carried out on plant leaves from the different treatments until the first symptoms were observed in $90 \%$ of the plants of a given species. Weekly assessments were performed afterwards. In the last assessment, the number of total leaves, healthy leaves, leaves presenting $\mathrm{O}_{3}$-specific symptoms and senescent leaves was recorded on three randomly selected stems or tillers per plant on Papilionaceae or Poaceae species, respectively. $T$. striatum and $T$. hirtum were not included in this last assessment. Injury intensity at the plant level was expressed as the percentage of affected to total assessed leaves.

\subsection{Ozone exposure indices}

The $\mathrm{O}_{3}$ exposure index AOT40 currently used by both the UN ECE CLRTAP ${ }^{1}$ and the European daughter $\mathrm{O}_{3}$ Directive $(2002 / 3 / \mathrm{EC})$ was calculated for the three $\mathrm{O}_{3}$ treatments integrating different periods: (a) from the beginning of plant exposure in the chambers until the first visible injury was detected, (b) from the beginning of plant exposure until the last assessment of visible injury was carried out, and (c) integrating the exposure during the 5 days preceding the detection of $\mathrm{O}_{3}$ injury and determining whether air VPD was below or above $1.5 \mathrm{kPa}$ during this period. The AOT40 index was calculated as the sum of the differences between $\mathrm{O}_{3}$ hourly concentrations in $\mathrm{nll}^{-1}$ and $40 \mathrm{nll}^{-1}$ for each hour when concentration exceeds $40 \mathrm{n}^{-1}$ and solar radiation is above $50 \mathrm{~W} \mathrm{~m}^{-2}$.

Ozone exposure throughout the experiment was also calculated using other indices such as AOT30 (accumulated exposure over the cut-off of $30 \mathrm{nll}^{-1}$ ), AOT60 (accumulated exposure over the cut-off of $60 \mathrm{nl}^{-1}$ ) and the number of hours presenting $\mathrm{O}_{3}$ levels above 30,40 and $60 \mathrm{nl}^{-1}$ (NUM30, NUM40 and NUM60, respectively). In addition, $\mathrm{O}_{3}$ 10-h mean (07:00-17:00 GMT), the 24-h $\mathrm{O}_{3}$ mean, the number of days where the $\mathrm{O}_{3}$ daily mean exceeded $33 \mathrm{nl}^{-1}$ (D33), the number of hourly averages exceeding $100 \mathrm{nll}^{-1}$ (NUM100) and the maximum hourly levels (Max. hourly levels) were also determined.

\subsection{Statistical analyses}

Ozone effects on visible injury-related parameters were tested performing an ANOVA analysis for each species and variable. In addition, a two-way ANOVA analysis using $\mathrm{O}_{3}$ treatment and family as factors was carried out to assess whether a given family could be associated with differential $\mathrm{O}_{3}$ sensitivity. When significant differences $(p<0.05)$ were detected, the differences between means were assessed using the leastsignificant difference (LSD) test. The validation process and the assumptions of analyses of variance followed using Shappiro-Wilk's W and Levenne tests to check the normal distribution and homogeneous variance, respectively. When non-compliance with ANOVA assumptions was observed, data transformation followed, using angular transformations ( $\arcsin x^{0.5}$ ) of data expressed as percentages.

The relationship between visible injury records and the different $\mathrm{O}_{3}$ exposure indices was analysed using Pearson's correlation index and the level of significance

\footnotetext{
${ }^{1}$ UN ECE CLRTAP stands for United Nations/Economic Commission for Europe Convention on Long-Range Transboundary Air Pollution.
} 
Table 1

Experimental protocol and ozone exposure related with the induction of foliar visible injury on the Papilionaceae species involved in the screening experiment

\begin{tabular}{|c|c|c|c|c|c|c|c|c|c|c|}
\hline \multirow[t]{2}{*}{ Papilionaceae } & \multirow{2}{*}{$\begin{array}{l}\text { Plant entrance } \\
\text { in OTC }\end{array}$} & \multirow{2}{*}{$\begin{array}{l}\text { Total exposure } \\
\text { length (days) }\end{array}$} & \multicolumn{4}{|l|}{ NFA } & \multicolumn{4}{|l|}{$\mathrm{NFA}+$} \\
\hline & & & $\begin{array}{l}\text { Time length } \\
\text { injury } \\
\text { develop }^{a} \\
\text { (days) }\end{array}$ & $\begin{array}{l}\text { AOT40 } \\
\text { until } \\
\text { injury } \\
\left(\mathrm{nl} 1^{-1} \mathrm{~h}\right)\end{array}$ & $\begin{array}{l}\text { AOT40 } \\
\text { VPD }>1.5^{\mathrm{c}} \\
(5 \text { days }) \\
\left(\mathrm{n} 11^{-1} \mathrm{~h}\right)\end{array}$ & $\begin{array}{l}\text { AOT40 } \\
\text { VPD }<1.5^{\text {d }} \\
(5 \text { days }) \\
\left(\mathrm{nll}^{-1} \mathrm{~h}\right)\end{array}$ & $\begin{array}{l}\text { Time length } \\
\text { injury } \\
\text { develop }^{a} \\
\text { (days) }\end{array}$ & $\begin{array}{l}\text { AOT40 } \\
\text { until } \\
\text { injury } \\
\left(\mathrm{n} 11^{-1} \mathrm{~h}\right)\end{array}$ & $\begin{array}{l}\text { AOT40 } \\
\text { VPD }>1.5^{\mathrm{c}} \\
(5 \text { days }) \\
\left(\mathrm{nll}^{-1} \mathrm{~h}\right)\end{array}$ & 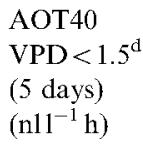 \\
\hline Anthyllis cornicina $\mathrm{L}$. & $07 / 09 / 00$ & 76 & - & - & - & - & - & $15,189^{\mathrm{e}}$ & - & - \\
\hline Anthyllis lotoides $\mathrm{L}$. & $14 / 09 / 00$ & 69 & - & - & - & - & - & $13,144^{\mathrm{e}}$ & - & - \\
\hline Biserrula pelecinus $\mathrm{L}$. & $22 / 09 / 00$ & 67 & 67 & 313 & 0 & 0 & 28 & 5698 & 0 & 1086 \\
\hline Medicago minima (L.) Bartal & $11 / 10 / 00$ & 43 & - & - & - & - & 28 & 3942 & 0 & 788 \\
\hline Ornithopus compressus L. & $11 / 10 / 00$ & 66 & - & - & - & - & - & $12,099^{\mathrm{e}}$ & - & - \\
\hline Trifolium angustifolium $\mathrm{L}$. & $11 / 10 / 00$ & 43 & 28 & 67 & 0 & 0 & 28 & 3942 & 0 & 788 \\
\hline Trifolium cherleri $\mathrm{L}$. & $08 / 09 / 00$ & 77 & 5 & 359 & 17 & 342 & 5 & 1432 & 186 & 1247 \\
\hline Trifolium glomeratum $\mathrm{L}$. & $08 / 09 / 00$ & 68 & 5 & 359 & 17 & 342 & 5 & 1432 & 186 & 1247 \\
\hline Trifolium hirtum All. & $22 / 09 / 00$ & 47 & 47 & 288 & 0 & 0 & 13 & 2956 & 108 & 711 \\
\hline Trifolium striatum $\mathrm{L}$. & $14 / 09 / 00$ & 61 & 1 & 17 & 0 & 301 & 1 & 226 & 0 & 1776 \\
\hline Trifolium subterraneum $\mathrm{L}$. & $08 / 09 / 00$ & 66 & 5 & 359 & 17 & 342 & 5 & 1432 & 186 & 1247 \\
\hline
\end{tabular}

${ }^{\mathrm{a}}$ Time length for the detection of the first visible injury.

${ }^{b}$ Accumulated ozone exposure over $40 \mathrm{nl}^{-1}$ (AOT40) from the start of the experiment until the observation of the first foliar injury.

${ }^{\mathrm{c}}$ Integrated ozone exposure 5 days prior to the detection of the first foliar injury when air vapour pressure deficit (VPD) was above $1.5 \mathrm{kPa}$, respectively, for the non-filtered air (NFA) or non-filtered air supplemented with $40 \mathrm{nl} \mathrm{I}^{-1} \mathrm{O}_{3}$ treatments (NFA+).

${ }^{\mathrm{d}}$ Integrated ozone exposure 5 days prior to the detection of the first foliar injury when air vapour pressure deficit (VPD) was below $1.5 \mathrm{kPa}$, respectively, for the non-filtered air (NFA) or non-filtered air supplemented with $40 \mathrm{nl} \mathrm{I}^{-1} \mathrm{O}_{3}$ treatments (NFA+).

${ }^{\mathrm{e}}$ Ozone exposure throughout the experiment, no visible injury was found in these species. 
Table 2

Experimental protocol and ozone exposure related with the induction of foliar visible injury on the Poaceae species involved in the screening experiment

\begin{tabular}{|c|c|c|c|c|c|c|c|c|c|c|}
\hline \multirow[t]{2}{*}{ Poaceae } & \multirow{2}{*}{$\begin{array}{l}\text { Plant entrance } \\
\text { in OTC }\end{array}$} & \multirow{2}{*}{$\begin{array}{l}\text { Total exposure } \\
\text { length (days) }\end{array}$} & \multicolumn{4}{|l|}{ NFA } & \multicolumn{4}{|l|}{$\mathrm{NFA}+$} \\
\hline & & & $\begin{array}{l}\text { Time length } \\
\text { injury develop } \\
\text { (days) }\end{array}$ & $\begin{array}{l}\text { AOT } 40 \\
\text { until injury } \\
\left(\mathrm{nll}^{-1} \mathrm{~h}\right)\end{array}$ & $\begin{array}{l}\text { AOT } 40 \\
\text { VPD }>1.5^{\mathrm{c}} \\
(5 \text { days }) \\
\left(\mathrm{nl} 1^{-1} \mathrm{~h}\right)\end{array}$ & $\begin{array}{l}\text { AOT40 } \\
\text { VPD }<1.5^{\mathrm{d}} \\
(5 \text { days }) \\
\left(\mathrm{nl} 1^{-1} \mathrm{~h}\right)\end{array}$ & $\begin{array}{l}\text { Time length } \\
\text { injury develop } \\
\text { (days) }\end{array}$ & $\begin{array}{l}\text { AOT } 40 \\
\text { until injury } \\
\left(\mathrm{nl} \mathrm{l}^{-1} \mathrm{~h}\right)\end{array}$ & $\begin{array}{l}\text { AOT } 40 \\
\text { VPD }>1.5^{\mathrm{c}} \\
(5 \text { days }) \\
\left(\mathrm{nl} 1^{-1} \mathrm{~h}\right)\end{array}$ & 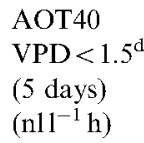 \\
\hline Aegilops geniculata Roth & $07 / 09 / 00$ & 71 & 43 & 776 & 0 & 47 & 28 & 7002 & 108 & 711 \\
\hline Aegilops triuncialis $\mathrm{L}$. & $07 / 09 / 00$ & 72 & - & - & - & - & 28 & 7002 & 108 & 711 \\
\hline Avena barbata Link & $11 / 10 / 00$ & & 28 & 67 & 0 & 0 & 9 & 1480 & 0 & 1086 \\
\hline Avena sterilis $\mathrm{L}$. & $03 / 10 / 00$ & 49 & 35 & 160 & 0 & 0 & 17 & 3411 & 0 & 1086 \\
\hline Briza maxima $\mathrm{L}$. & $20 / 09 / 00$ & 63 & - & - & - & - & 28 & 8934 & 0 & 788 \\
\hline Bromus hordeaceus $\mathrm{L}$. & $07 / 09 / 00$ & 69 & - & - & - & - & 61 & 12,206 & 108 & 711 \\
\hline Bromus steritis L. & $14 / 09 / 00$ & 67 & - & - & - & - & 54 & 10,160 & 0 & 788 \\
\hline Cynosurus echinatus L. & $14 / 09 / 00$ & 68 & - & - & - & - & - & $12,794^{\mathrm{e}}$ & - & - \\
\hline Lolium rigidum Gaudin & $11 / 10 / 00$ & 43 & - & - & - & - & 9 & 1480 & 0 & 1086 \\
\hline
\end{tabular}

${ }^{a}$ Time length for the detection of the first visible injury.

${ }^{b}$ Accumulated ozone exposure over $40 \mathrm{nl}^{-1}$ (AOT40) from the start of the experiment until the observation of the first foliar injury.

${ }^{\mathrm{c}}$ Integrated ozone exposure 5 days prior to the detection of the first foliar injury when air vapour pressure deficit (VPD) was above $1.5 \mathrm{kPa}$, respectively, for the non-filtered air (NFA) or non-filtered air supplemented with $40 \mathrm{nll}^{-1} \mathrm{O}_{3}$ treatments (NFA+)

${ }^{\mathrm{d}}$ Integrated ozone exposure 5 days prior to the detection of the first foliar injury when air vapour pressure deficit (VPD) was below $1.5 \mathrm{kPa}$, respectively, for the non-filtered air (NFA) or non-filtered air supplemented with $40 \mathrm{nll}^{-1} \mathrm{O}_{3}$ treatments (NFA + ).

${ }^{e}$ Ozone exposure throughout the experiment, no visible injury was found in these species. 
was determined using the Student's $t$-test. All statistical analyses were carried out using Statistica 5.1. software.

\section{Results and discussion}

Ozone induced the appearance of specific and senescence-related foliar symptoms in 16 of the 22 assessed species. Both families (Poaceae and Papilionaceae) presented $\mathrm{O}_{3}$-sensitive species, although differences in the type of injury, the number of affected species and the extent of visible injury on their foliage were found between them.

Ozone-induced injury on Papilionaceae species consisted of brown-reddish necrotic spots that were associated with foliar chlorosis in the case of $T$. angustifolium and Medicago minima. The Trifolium genus was the most $\mathrm{O}_{3}$-sensitive taxa since all the assessed species showed visible symptoms following short $\mathrm{O}_{3}$ exposures under ambient or close to ambient concentrations, in agreement with the results reported by Nebel and Fuhrer (1994). This is a finding of concern, since it is the most predominant genus in the therophytic and siliceous pastures of the Iberian Peninsula (Allué Andrade and Tella, 1986).

The $\mathrm{O}_{3}$ sensitivity ranking of the assessed Papilionaceae species was: $T$. striatum $>T$. cherleri, $T$. glomeratum, T. subterraneum, T. hirtum $>T$. angustifolium $>$ Biserrula pelecinus, M. minima $>$ Anthyllis lotoides, A. cornicina, O. compressus.

T. striatum was the most sensitive species of this genus; $\mathrm{O}_{3}$-induced injury was observed in the first fully expanded trifoliate even before the plants were introduced in the chambers, associated with a very low AOT40 value, $17 \mathrm{nl}^{-1} \mathrm{~h}$ (Table 1). T. cherleri, T. glomeratum, T. subterraneum and T. hirtum were rather sensitive to $\mathrm{O}_{3}$ exposure since the first $\mathrm{O}_{3}$ visible injury was found with AOT40 values ranging $288-359 \mathrm{nl}^{-1} \mathrm{~h}$ (Table 1). These values are much lower than those reported by Bergmann et al. (1999) for 25 species of German flora, ca. $2000 \mathrm{nll}^{-1} \mathrm{~h}$. In fact, when the $\mathrm{O}_{3}$ exposure corresponding to the 5 days prior to the first observation of injury was considered, the AOT40 values ranged from 0 to 17 when $\mathrm{VPD}>1.5 \mathrm{kPa}$ and from 0 to 342 when $V P D<1.5 \mathrm{kPa}$. These values are lower than the $200-500 \mathrm{nl}^{-1}$ range reported for the induction of visible injury on a pan-European study involving $T$. subterraneum (Benton et al., 2000). A gradation in foliar injury (both $\mathrm{O}_{3}$-induced visible injury and senescent leaves) was found in the Papilionaceae group when plants were exposed to the different treatments for 66-77 days (Fig. 1); the extent of visible injury increased $(p<0.05)$ in NFA and NFA + plants by $45-60 \%$ and $75-85 \%$, respectively, when compared with CFA plants.

The first foliar injury on $T$. angustifolium was found at a rather low AOT40 value $\left(67 \mathrm{nll}^{-1} \mathrm{~h}\right)$; however, injury developed at a low rate after 43 days of exposure and only affected $10 \%$ of the foliage of NFA + plants (Table 1 , Fig. 1). Ozone exposure did not induce an increase in senescence-related symptoms. This behaviour would indicate a greater sensitivity of early stages of development when compared to late phenological stages. Franzaring et al. (2000) also reported more resistant and robust leaves in the later stages, while Carlsson et al. (1996) found an inverse relationship. However, in this species, $\mathrm{O}_{3}$ exposure appears to be related with the induction and extension of interveinal chlorosis in the trifoliates (not quantified). This type of injury was not found in any other of the assessed Trifolium species and is considered as a non-specific $\mathrm{O}_{3}$ injury.

B. pelecinus and $M$. minima could be considered as less sensitive than Trifolium species since ambient $\mathrm{O}_{3}$ levels induced foliar injury $B$. pelecinus only at the end of the experiment and did not determine any effect on $M$. minima. Moreover, the first foliar injury was observed in the NFA + plants of both species after 28 days of exposure in association with AOT40 values in the 3942 $5698 \mathrm{nll}^{-1} \mathrm{~h}$ range (Table 1). B. pelecinus would be slightly more sensitive than $M$. minima since after 67 days of exposure $\mathrm{O}_{3}$-induced injury was found in $20 \%$ of the leaves of NFA and NFA + plants and an increment of senescence in NFA + leaves was also found $(p<0.05)$ (Fig. 1).

$A$. cornicina, $A$. lotoides and $O$. compressus can be considered as the most resistant species to $\mathrm{O}_{3}$ exposure as no effects were detected on their leaves after an average exposure length of 70 days, with AOT40 values up to $12,000-15,000 \mathrm{nl} \mathrm{l}^{-1} \mathrm{~h}$ in the NFA + treatment (Table 1). Foliage was apparently healthy and $\mathrm{O}_{3}$ exposure did not cause an increased senescence in these species (Table 1).

The $\mathrm{O}_{3}$-induced foliar injury observed in the species of the Poaceae family was different from that observed in the Papilionaceae species. Apical necrosis and reddishbrown spots parallel to leaf's nerves were observed in Avena sterilis and $A$. barbata. Apical necrosis followed by a chlorotic banding parallel to leaf's nerves was found in Aegilops geniculata and A. triuncialis. Ozone exposure induced in $67 \%$ of Poaceae species an increase in all the senescent-related parameters assessed: number of senescent leaves to total leaves ratio, dry weight of total senescent foliage per plant or green biomass to senescent biomass ratio. Therefore, senescence appears to be a crucial parameter to determine the $\mathrm{O}_{3}$ sensitivity of the dehesa therophytic species of the Poaceae family.

Also, the grass species were classified regarding their $\mathrm{O}_{3}$ sensitivity considering the $\mathrm{O}_{3}$ exposure needed for the induction of foliar visible injury symptoms: $A$. barbata, A. sterilis, A. geniculata $>$ Lolium rigidum $>$ Briza maxima, A. triuncialis, Bromus hordeaceus, B. sterilis > Cynosurus echinatus, Micropyrum tenellum, Vulpia myuros. 
Biserrula pelecinus

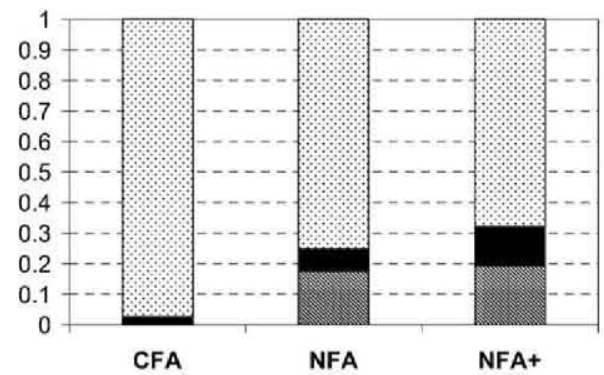

Trifolium subterraneum

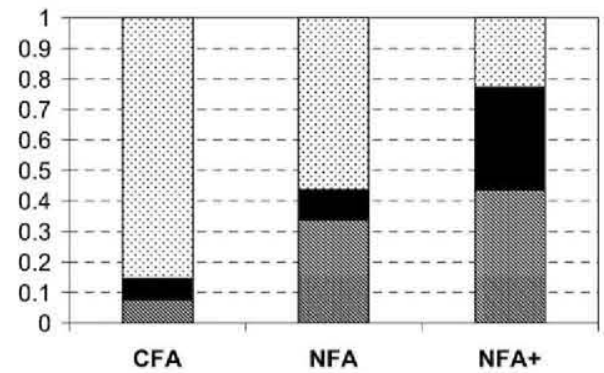

Trifolium angustifolium

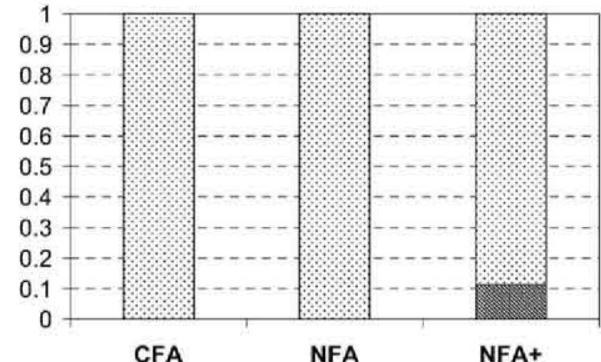

Medicago minima

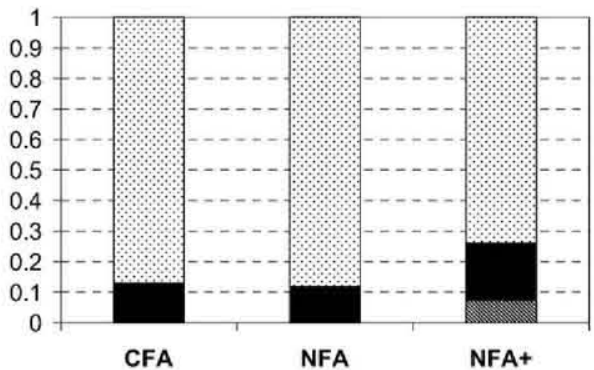

Trifolium cherleri

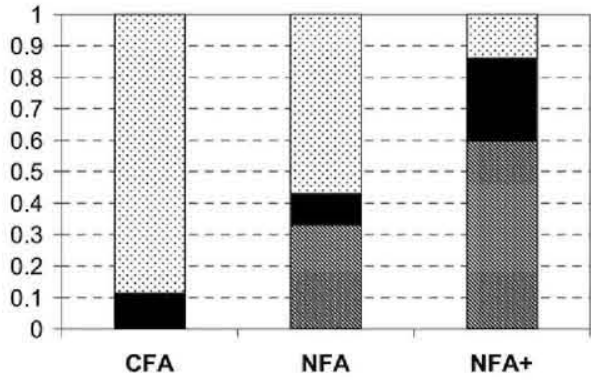

Trifolium glomeratum

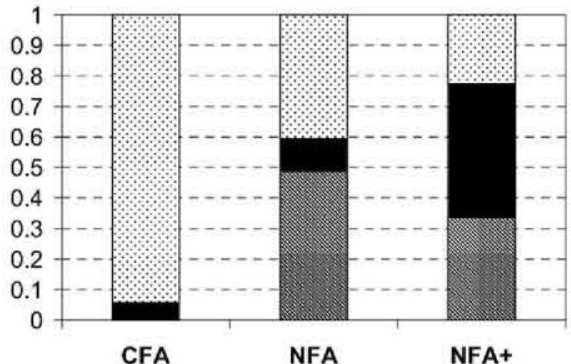

Fig. 1. Foliar injury (\%) of the Papilionaceae species involved in the experiment. = senescence-related injury; $\ldots$ healthy foliage. $\mathrm{CFA}=$ charcoal-filtered air; NFA = non-filtered air; NFA $+=$ non-filtered air supplemented with $40 \mathrm{nll}^{-1}$ ozone.

A. barbata, $A$. sterilis and $A$. geniculata would be the most sensitive grasses since $\mathrm{O}_{3}$ foliar injury was observed after $28-43$ days of ambient $\mathrm{O}_{3}$ exposure corresponding to AOT40 values ranging $67-776 \mathrm{nll}^{-1} \mathrm{~h}$ (Table 2). At the end of the experiment, ambient $\mathrm{O}_{3}$ levels induced specific visible symptoms on about $20 \%$ of the leaves of $A$. sterilis and $A$. geniculata compared to control $(p<0.05)$ (Fig. 2). In the case of $A$. geniculata, ambient $\mathrm{O}_{3}$ levels also determined a $20 \%$ increase in foliar senescence $(p<0.01)$.

Foliar injury was also observed in other species, but a greater accumulated $\mathrm{O}_{3}$ exposure was needed to trigger visible injury on their foliage. For instance, the first foliar injury in L. rigidum was found in leaves of NFA + plants exposed to an AOT40 value of $1480 \mathrm{nll}^{-1} \mathrm{~h}$ (Table 2). At the end of the experiment, $\mathrm{O}_{3}$ foliar damage increased in NFA and NFA + compared to control $(p<0.01)$, but no differences between NFA and $\mathrm{NFA}+$ plants with regard to the number of $\mathrm{O}_{3}$-affected leaves were found. However, a significant gradation in the number of senescent leaves from the different $\mathrm{O}_{3}$ treatments was observed in this species $(p<0.01)$ (Fig. 2).

The group constituted by $A$. triuncialis, $B$. hordeaceus, $B$. sterilis and $B$. maxima could be considered as less sensitive since the first $\mathrm{O}_{3}$-induced visible injury was found following AOT40 exposures ranging 7000$12,200 \mathrm{nll}^{-1} \mathrm{~h}$ (Table 2). When the extension of visible injury was analysed at the end of the experiment, $B$. maxima was the most sensitive species within this group since the NFA and NFA + treatments induced a similar extent of injury on its foliage (Fig. 2). A. triuncialis 

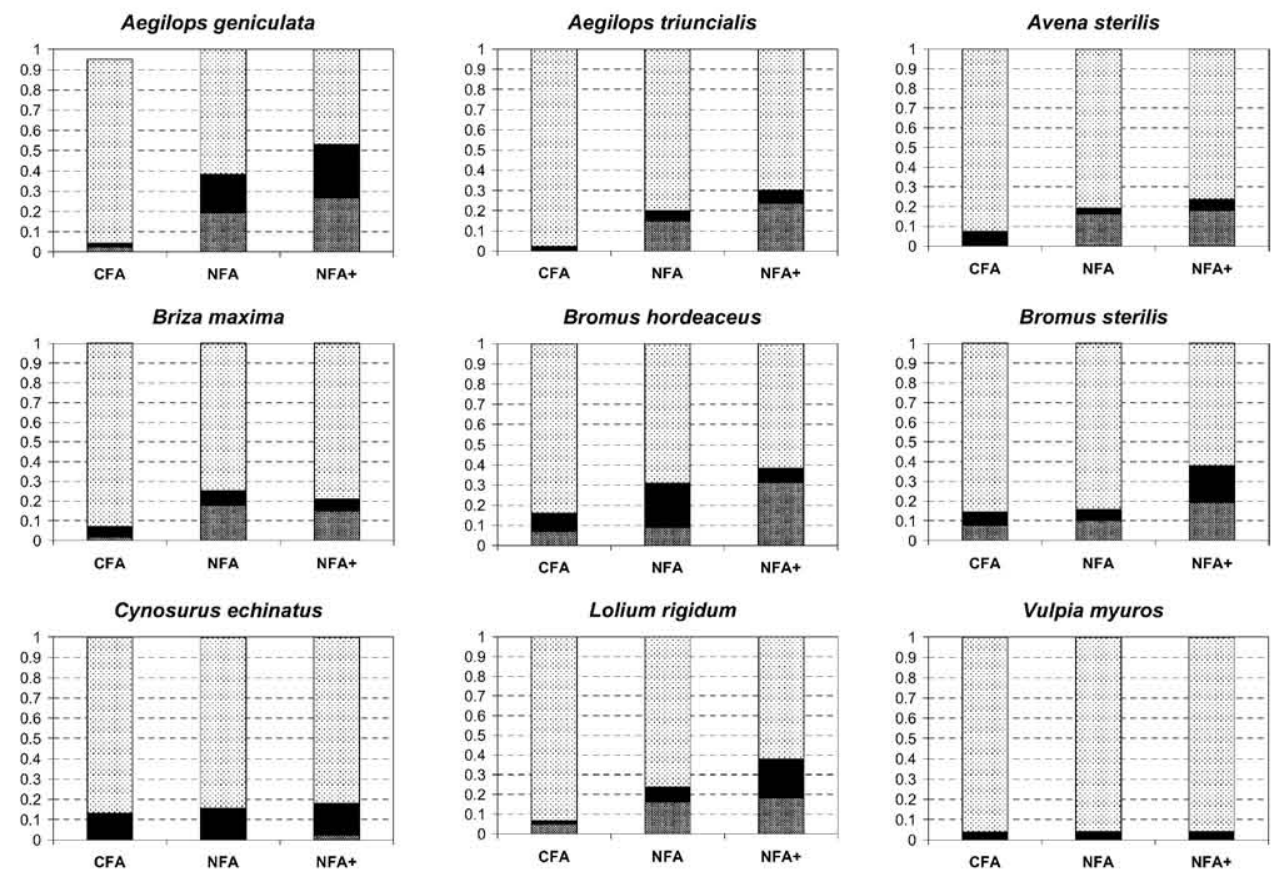

Fig. 2. Foliar injury (\%) of the Poaceae species involved in the experiment. related injury; $\mathrm{B}=$ healthy foliage. $\mathrm{CFA}=$ charcoal-filtered air; $\mathrm{NFA}=$ non-filtered air; $\mathrm{NFA}+=$ non-filtered air supplemented with $40 \mathrm{nll}^{-1}$ ozone.

would be the next sensitive species with a marked gradation in the development of foliar injury between the different treatments $(p<0.05)$. An increase in the extension of $\mathrm{O}_{3}$ foliar injury was found only in those $B$. hordeaceus plants exposed to the NFA + treatment when compared to control plants $(p<0.05)$ (Fig. 2). An increase in senescence following $\mathrm{O}_{3}$ exposure in NFA+ was observed in B. sterilis $(p<0.05)$, an effect that was not observed in the other species of this group. The increase in the number of senescent leaves is an unspecific but characteristic effect of this pollutant on natural vegetation (Bergmann et al., 1999; Franzaring et al., 2000). In fact, the ratio between the number of senescent leaves to total leaves recorded at the end of the experiment was more sensitive than the induction of specific symptoms following the exposure of B. sterilis individuals to increasing $\mathrm{O}_{3}$ concentrations.

The most $\mathrm{O}_{3}$-resistant grass species regarding visible injury were C. echinatus, M. tenellum and $V$. myuros, species that did not show any effect on their foliage, either as specific $\mathrm{O}_{3}$ symptoms or as senescence-related injury (Table 2).

The Papilionaceae species assessed in the experiment were more sensitive to $\mathrm{O}_{3}$ than the Poaceae species. Ambient $\mathrm{O}_{3}$ exposures involving AOT40 values close to $300 \mathrm{nll}^{-1} \mathrm{~h}$ and relatively short time lengths induced foliar visible symptoms in $67 \%$ of Papilionaceae species. By contrast, ambient $\mathrm{O}_{3}$ exposures determined the appearance of foliar symptoms in only $27 \%$ of Poaceae plants, and usually $\mathrm{O}_{3}$ exposures with AOT40 values over $1000 \mathrm{nll}^{-1} \mathrm{~h}$ were needed to induce foliar injury in the majority of the species of this family (Tables 1 and 2).

When the proportion of healthy, senescent and injured leaves was considered, $\mathrm{O}_{3}$ impact was the greatest in the Papilionaceae family as revealed by the two-way ANOVA analysis considering family and ozone as factors (Table 3 ). The extent of visible injury was influenced by both family and $\mathrm{O}_{3}$ treatment $(p<0.0001)$. $\mathrm{An}_{3}$-family interaction $(p<0.05)$ was found for the percentage of senescent leaves, since the NFA+ Papilionaceae plants presented an increase of $37 \%$ of senescent leaves when compared with the Poaceae plants of the same treatment.

When overall data were analysed, $\mathrm{O}_{3}$-induced foliar injury was recorded in association with $\mathrm{O}_{3}$ exposures well below current $\mathrm{O}_{3}$ short-term critical levels (see Tables 1 and 2). This was especially true when air VPD was higher than $1.5 \mathrm{kPa}$. Under these conditions, $\mathrm{O}_{3}$ visible injury was found associated with AOT40 values below the proposed $500 \mathrm{nll}^{-1} \mathrm{~h} \mathrm{O}_{3}$ threshold, in the ranges from $0-17$ to $0-186 \mathrm{nl}^{-1} \mathrm{~h}$ for the most sensitive species when exposed to ambient or artificially supplemented $\mathrm{O}_{3}$ levels respectively. Therefore, the present $\mathrm{O}_{3}$ critical level for visible injury does not appear to protect the species from dehesa ecosystems. This conclusion is in agreement with the findings reported by Tonneijck and Van Dijk (2002) for T. subterraneum. 
Table 3

Extent of foliar injury in Papilionaceae and Poaceae taxa at the end of the exposure period

\begin{tabular}{llll}
\hline Factor & $\begin{array}{l}\text { \% of leaves showing } \\
\text { specific } \mathrm{O}_{3} \text { injury }\end{array}$ & $\begin{array}{l}\text { \% of leaves showing } \\
\text { senescence-related injury }\end{array}$ & $\begin{array}{l}\% \text { of healthy } \\
\text { leaves }\end{array}$ \\
\hline $\mathrm{O}_{3}$ & $<0.0001$ & $\mathrm{~ns}$ & $<0.0001$ \\
Family & $<0.0001$ & $<0.0001$ & $<0.0001$ \\
$\mathrm{O}_{3} \times$ Family & $\mathrm{ns}$ & $<0.05$ & $<0.1$ \\
Papilionaceae & & & $0.86 \pm 0.04$ \\
CFA & $0.09 \pm 0.04$ & $0.06 \pm 0.01^{\mathrm{a}}$ & $0.63 \pm 0.05$ \\
NFA & $0.30 \pm 0.05$ & $0.07 \pm 0.01^{\mathrm{a}}$ & $0.48 \pm 0.06$ \\
NFA & $0.32 \pm 0.04$ & $0.19 \pm 0.03^{\mathrm{c}}$ & \\
Poaceae & & & $0.90 \pm 0.01$ \\
CFA & $0.03 \pm 0.01$ & $0.06 \pm 0.01^{\mathrm{a}}$ & $0.79 \pm 0.02$ \\
NFA & $0.11 \pm 0.01$ & $0.09 \pm 0.01^{\mathrm{ab}}$ & $0.71 \pm 0.03$ \\
NFA & $0.17 \pm 0.02$ & $0.12 \pm 0.01^{\mathrm{b}}$ & \\
\hline
\end{tabular}

Different letters indicate significant differences among ozone treatments. $C F A=$ charcoal-filtered air; NFA=non-filtered air; $\mathrm{NFA}+=$ non-filtered air supplemented with $40 \mathrm{n} 11^{-1} \mathrm{O}_{3}$. Mean values \pm standard errors.

The extent of $\mathrm{O}_{3}$-induced injury on plant foliage was more related with plant performance than the appearance of the first visible injury. Correlation analyses between the extent of foliar injury in Papilionaceae or Poaceae plants and different $\mathrm{O}_{3}$ exposure indices were carried out. Only significant relationships $(p<0.05)$ are commented below. The average exposure indices, such as M24 or M10, and indices based on a cut-off of $30 \mathrm{nl}^{-1}$, such as AOT30 or NUM30, performed better than AOT40 index in explaining the extent of visible injury on the assessed plant species. The performance of these indices depended on the type of injury. The extent of specific $\mathrm{O}_{3}$ injury was best explained $(r=0.85)$ by NUM30 in the Papilionaceae plants, while it was almost equally explained by M10, M24, NUM30 or maximum hourly values $(0.62<r \leqslant 0.65)$ in the Poaceae species.

Interestingly, the NUM30 $(r=0.85)$ and NUM40 $(r=0.70)$ indices performed better than the AOT30 $(r=0.66)$ and AOT40 $(r=0.60)$ indices, respectively, in explaining the extent of $\mathrm{O}_{3}$-specific injury on the foliage of Papilionaceae plants. This would indicate that all concentrations above a given threshold are equally phytotoxic since the AOT-type indices implicitly provide more weight to the higher $\mathrm{O}_{3}$ concentrations (Tuovinen, 2000 ) and would be related with the high $\mathrm{O}_{3}$ sensitivity of this taxon.

The extent of leaf senescence in Papilionaceae plants was almost equally explained by AOT30, AOT40, NUM40, AOT60 or NUM60 indices $(0.74<r<0.76)$. In the case of Poaceae plants, this parameter was also almost equally explained by NUM30, AOT30, M24, M10, maximum hourly values and NUM40 $(0.37<r<0.40)$.
The number of hours where $\mathrm{O}_{3}$ concentrations were above the cut-off of $30 \mathrm{nl}^{-1}$ (NUM30) was the index that best explained the total extent of $\mathrm{O}_{3}$-induced foliar injury (specific $\mathrm{O}_{3}$ injury plus senescent foliage) in both Papilionaceae $(r=0.87)$ and Poaceae species $(r=0.68)$. Regression equations were constructed separately to predict the response of both families to $\mathrm{O}_{3}: \%$ affected leaves in Papilionaceae plants $=0.0911$ NUM30 $\left(R^{2}=0.76\right)$ and $\%$ affected leaves in Poaceae plants $=0.0369$ NUM30 $\left(R^{2}=0.47\right)$. Exposures to 55 and $110 \mathrm{~h}$ over $30 \mathrm{nll}^{-1}$ would be needed to determine $5 \%$ and $10 \%$ injury on the foliage of Papilionaceae species, respectively. Similarly, $5 \%$ and $10 \%$ foliage damage on Poaceae species would appear when exposed to 136 and $271 \mathrm{~h}$ over $30 \mathrm{nll}^{-1}$ of $\mathrm{O}_{3}$.

Since visible injury was observed in association with zero AOT40 values accumulated during the 5 days preceding the detection of $\mathrm{O}_{3}$ injury, our results suggest that a cut-off lower than $40 \mathrm{nll}^{-1}$ should be considered for adequate plant protection. This is in agreement with the findings of Pihl Karlsson et al. (1995) for T. subterraneum and Ribas and Peñuelas (2003) for tobacco cv. Bel-W3. A meta-analysis is envisaged to ascertain whether this proposal is valid when data from pan-European observations and experimentation are analysed.

\section{Conclusions}

The results of our experiments indicate the great $\mathrm{O}_{3}$ sensitivity of the therophytic plants from dehesa ecosystems based on the induction of $\mathrm{O}_{3}$ visible injury. The Papilionaceae plants, particularly those belonging 
to the Trifolium genus, were more sensitive than the Poaceae species. Ozone induced both symptomatic and asymptomatic (senescence-related) foliar injury on some species at exposures well below current short-term critical levels. Therefore, indices based on a cut-off of $30 \mathrm{nll}^{-1}$ instead of current $40 \mathrm{nll}^{-1}$ threshold are proposed. These species could be useful in future $\mathrm{O}_{3}$ bioindication programmes focused in the Mediterranean area.

\section{Acknowledgements}

This research has been performed under the framework of the UN ECE ICP-Vegetation and funded by the EU BIOSTRESS project, Contract EVK2-C-199900040. Thanks are given to Modesto Mendoza, Sonia Sánchez and Rosa Inclán for their help during field work and to Dr. César Gómez Campos (ETSI Agrónomos, Madrid), Dr. Francisco González López (Servicio de Investigación y Desarrollo Tecnológico, DG. de Producción, Investigación y Formación Agraria, Consejería de Agricultura y Medio Ambiente, Comunidad de Extremadura) and José Cebolla (ETSI Montes, Madrid) for their co-operation in seed supply.

\section{References}

Alonso, R., Elvira, S., Castillo, F.J., Gimeno, B.S., 2001. Interactive effects of ozone and drought stress on pigments and activities of oxidative enzymes in Pinus halepensis. Plant Cell and Environment 24, 905-916.

Allué Andrade, J.L., Tella, G., 1986. Los pastos españoles. II. Clasificación, composición, atributos y mejora de sus principales tipos florísticos. E.U.I.T. Forestal, Madrid, Spain.

Ashmore, M.R., Dalpra, C., Tickle, A.K., 1987. Effects of ozone and calcium nutrition on native plant species. In: Mathy, P. (Ed.), Air pollution and ecosystems. Reidel, Dordrecht, The Netherlands, pp. 647-652.

Ashmore, M.R., Thwaites, R.H., Aisnworth, N., Cousins, D.A., Power, S.A., Morton, J., 1995. Effects of ozone on calcareous grassland communities. Water, Air and Soil Pollution 85, 1527-1532.

Benton, J., Fuhrer, J., Gimeno, B.S., Skärby, L., PalmerBrown, D., Ball, G., Roadknight, C., Mills, G., 2000. An international co-operative programme indicates the widespread occurrence of ozone injury on crops. Agriculture, Ecosystems and Environment 78, 19-30.

Bermejo, V., Gimeno, B.S., Granados, I., Santamaría, J., Irigoyen, J.J., Bermejo, R., Porcuna, J.L., Mills, G., 2002. Investigating indices to explain the impacts of ozone on the biomass of white clover (Trifolium repens L. cv. Regal) at inland and coastal sites in Spain. New Phytologist 156, 43-55.

Bergmann, E., Bender, J., Weigel, H-J., 1999. Ozone threshold doses and exposure-response relationships for the develop- ment of ozone injury symptoms in wild plant species. New Phytologist 144, 423-435.

Carlsson, A.S., Wallin, G., Sandelius, A.S., 1996. Speciesand age-dependent sensitivity to ozone in young plants of pea, wheat and spinach, effects on acyl lipid and pigment content and metabolism. Physiologia Plantarum 98, 271-280

Davison, A.W., Barnes, J.D., 1998. Effects of ozone on wild plants. New Phytologist 139, 135-151.

EMEP, 2002.Transboundary acidification, eutrophication and ground level ozone in Europe. EMEP Report 1 and 2/2002. EMEP, Oslo, Norway.

Franzaring, J., Tonneijck, A.E.G., Koijman, A.W.N., Dueck, Th.A., 2000. Growth responses to ozone in plant species from wetlands. Environmental and Experimental Botany 44, 39-48.

Fuhrer, J., Acherman, B. (Eds.), 1999. Critical Levels for Ozone-Level II. Environmental Documentation 115. Swiss Agency for Environment, Forests and Landscape, Bern, Switzerland.

Fuhrer, J., Shariat-Madari, H., Perler, R., Tschannen, W., Grub, A., 1994. Effects of ozone on managed pasture. II. Yield, species composition, canopy structure and forage quality. Environmental Pollution 83, 317-325.

Fumagalli, I., Gimeno, B.S., Velissariou, D., Mills, G., De Temmerman, L., Fuhrer, J., 2001. Evidence of ozoneinduced adverse effects on Mediterranean vegetation. Atmospheric Environment 35, 2583-2587.

Gimeno, B.S., Bermejo, V., Reinert, R.A., Zheng, Y., Barnes, J.D., 1999. Adverse effects of ambient ozone on watermelon yield and physiology at a rural site in Eastern Spain. New Phytologist 144, 245-260.

Madkour, S.A., Laurence, J.A., 2002. Egyptian plant species as new ozone indicators. Environmental Pollution 120 , 339-353.

Marañon, T., 1985. Diversidad florística y heterogeneidad ambiental en una dehesa de Sierra Morena. Anales de Edafología y Agrobiología 44, 1183-1197.

Myers, N., Mittermeier, R.A., Mittermeier, C.G., da Fonseca, C.A.B., Kent, J., 2000. Biodiversity hotspots for conservation priorities. Nature 403, 853-858.

Nali, C., Pucciariello, C., Lorenzini, G., 2002. Ozone distribution in central Italy and its effect on crop productivity. Agriculture, Ecosystems and Environment $90,277-289$

Nebel, B., Fuhrer, J., 1994. Inter- and intra-specific differences in ozone sensitivity in semi-natural plant communities. Angewandte Botanik 68, 116-121.

Peco, B., Espigares, T., Levassor, C., 1998. Trends and fluctuations in species abundance and richness in Mediterranean annual pastures. Applied Vegetation Science 1, 21-28.

Pihl Karlsson, G., Pleijel, H., Sild, E., Danielsson, H., Selldén, G., Ericson, L., Skärby, L., 1995. Clover Sweden-a national three year study of the effects of troposheric ozone on Trifolium subterraneum. Water, Air and Soil Pollution $85,1503-1508$.

Pineda, F.D., Nicolás, J.P., Ruiz, M., Peco, B., Bernáldez, F.G., 1981. Succesion, diversité et amplitude de niche dans les aturages du centre de la péninsule ibérique. Vegetatio 47 , 267-277. 
Plaza, J., Pujadas, M., Artínano, B., 1997. Formation and transport of the Madrid ozone plume. Journal of Air and Waste Management Association 47, 666-774.

Pleijel, H., Danielsson, H., 1997. Growth of 27 herbs and grasses in relation to ozone exposure and plant strategy. New Phytologist 135, 361-367.

Pujadas, M., Terés, J., Gimeno, B.S., 1997. La experiencia española en el diseño de sistemas experimentales para el estudio de efectos producidos por contaminantes gaseosos sobre especies vegetales. Boletín de Sanidad Vegetal-Plagas 23, 39-54.

Ribas, A., Peñuelas, J., 2003. Biomonitoring of tropospheric ozone phytotoxicity in rural Catalonia. Atmospheric Environment 37, 63-71.

Sala, O.E., Chapin III, F.J., Armesto, J.J., Berlow, E., Bloomfield, J., Dirzo, R., Huber-Sanwald, E., Huenneke, L., Jackson, R.B., Kinzig, A., Leemans, R., Lodge, D., Mooney, H., Oesterheld, M., Poff, N.L., Sykes, M.T.,
Walker, B.H., Walker, M., Wall, D.H., 2000. Global diversity scenarios for the year 2100 . Science 287 , 1770-1774.

San Miguel, A., 1994. La dehesa española. Origen, tipología, características y gestión. E.T.S.I. Montes, Madrid, Spain.

Tonneijck, A.E.G., Van Dijk, C.J., 2002. Injury and growth response of subterranean clover to ambient ozone as assessed by using ethylendiurea (EDU): three years of plant monitoring at four sites in the Netherlands. Environmental and Experimental Botany 48, 33-41.

Tuovinen, J.P., 2000. Assessing vegetation exposure to ozone: properties of the AOT40 index and modifications by deposition modelling. Environmental Pollution 109, 361-372.

UN ECE, 1988. ECE Critical Levels Workshop. BadHarzburg14-18 March 1988. Final Draft Report. Unwelbundesamt, Berlin, Germany. 